ments. Much of the material consists of useful practice notes about obscure legal and administrative procedures in different countries, e.g., customs clearances in Saudi Arabia, protection of copyright procedures pertaining to musical records in some developing countries, etc. There are also valuable travel hints about countries and cities frequented by attorneys with international practices. Perhaps the most interesting feature is the column about job vacancies for international business lawyers (predominantly in the United States).

Published six times a year (with each issue being about 20 pages long), the International Lawyers' Newsletter may be obtained for an annual subscription rate of US $\$ 25$ by writing to its editorial offices at:

2525 Royal Oaks Drive

Freeport, IL 61032

U.S.A.

or

De Lairessestraat 163

1075 HK Amsterdam

The Netherlands

\title{
A NEW PERUVIAN CIVIL CODE
}

In 1974 a special commission was established to draft a new Civil Code. It would replace the relatively outdated Code of 1936 which at the time of the drafting was modeled upon the German Civil Code (BGB) of the 1900. The commission consists of ten members, all of whom are eminent Peruvian jurists and experts in their respective fields of law. It is also significant that the President of the Commission, Dr. Felipe Osterling Parodi, is the current Minister of Justice in the recently elected government of Peru.

Members of the commission have already prepared drafts for their individually assigned areas of the proposed code:

Law of Persons (Dr. José León Barandiarán)

Family Law (Dr. Héctor Cornejo Chávez and Dr. Felipe Osterling Parodi)

Property Law (Dr. Jorge Avendaño and Dr. Lucrecia Maisch von Humboldt)

Contracts (Dr. Felipe Osterling Parodi, Dr. Max Arias Schreiber, and Dr. Manuel de la Puente y Lavalle)

Torts (Dr. Fernando de Trazegnies)

Inheritance Law (Dr. Rómulo Lanatta) 
Containing extensive explanatory notes and comments, these drafts have already been submitted for public discussion. A Code Revision Committee, consisting of senators and deputies who are lawyers, has been created by the Parliament in order to study and approve the prepared text which, according to a pre-established schedule, will be enacted into law on July 28, 1982, the 161th Anniversary of the Independence of Peru. It will be the third Civil Code in Peruvian legal history. Broadly based on the Italian Civil Code of 1941, the proposed draft nevertheless contains many innovative provisions, including principles of risk distribution developed in the tort law areas in the United States.

The text of the proposed draft code together with the explanatory notes and comments of its authors has been published in two volumes by the Catholic University Press, Apartado 1726, Lima, Peru. Consisting of 1600 pages, it is priced at US\$ 60 .

The drafting commission welcomes comments about the proposed code from legal experts abroad and at home. Such comments may be sent to the office of the Minister of Justice in Lima, Peru.

An important event for the proposed draft of the new Civil Code was its presentation to the President of the Peruvian Parliament, the Judges of the Supreme Court, and many distinguished foreign jurists who were attending the 5th Conference of the Ministers of Justice of Portugese- and Spanish-language countries and the Phillipines.

Fernando de Trazegnies 